\title{
Bio-treatment of maize processing wastewater using indigenous microorganisms
}

\author{
Ayman Y. I. Ewida(D)
}

\begin{abstract}
Wastewater arising from maize processing industry is rich in proteins, amino acids, carbohydrates and nitrogenous compounds. Discharging of such wastewaters to the main water bodies without proper treatment creates environmental risks. The present research aimed to reduce maize processing wastewater contaminants by indigenous microorganisms. Industrial wastewater samples of maize processing factory at 10th of Ramadan city, Egypt were collected. The chemical and microbiological characteristics of samples were evaluated. An in vitro batch experiment was conducted in triplicates using $5 \mathrm{~L}$ Erlenmeyer flasks enriched with $2 \mathrm{~L}$ of the maize processing wastewater and incubated under shaking ambient conditions at $120 \mathrm{rpm}$ for $30 \mathrm{~d}$. Another $2 \mathrm{~L}$ Erlenmeyer flask was enriched with $2 \mathrm{~L}$ of the wastewater sample, and incubated under static ambient conditions, used as control. The biodegradation of nitrogenous and organic compounds was followed up by measuring Total Kjeldahl Nitrogen (TKN), Biochemical Oxygen Demand (BOD), Chemical Oxygen Demand (COD), Dissolved Oxygen (DO) and pH. The biomass growth rate was monitored by counting the viable bacterial cells (TBC) and fungal cells. The concentration of TKN, BOD and COD was reduced from 2330, 9000 and 12,000 $\mathrm{mg} \mathrm{L}^{-1}$ to 420,220 and $430 \mathrm{mg} \mathrm{L}^{-1}$, respectively. DO concentrations were ranged between 6 to $12 \mathrm{mg} \mathrm{L}^{-1}$ and the $\mathrm{pH}$ value was elevated from 6.9 to 9.3. TBC was elevated from $2 \times 10^{6}$ to $4 \times 10^{10} \mathrm{CFU} \mathrm{mL}^{-1}$, while the yeast count was reduced from $12 \times 10^{6}$ to $2.2 \times 10^{4} \mathrm{CFU}$ $\mathrm{mL}^{-1}$. Microbial identification by Analytical Profile Index (API) profiling kits indicated that Saccharomyces cerevisiae, Bacillus subtilis, Bacillus amyloliquefaciens, and Bacillus licheniformis are the strains involved in bio-treatment.
\end{abstract}

Keywords: Bacteria, Bio-treatment, Maize, Yeast, Wastewater

\section{Introduction}

The rapid growth of industries has enhanced the productivity and release of toxic substances into the environment, which creates health hazards. It has seriously affected the normal operations of ecosystems [1]. In the past, considerable attention has been paid to the industrial wastewaters, which are usually discharged on land or into different water bodies, resulting in the degradation of the aqueous environment [2]. Various physical and chemical techniques have been applied for wastewaters treatment, including; sedimentation, aeration, filtration, flotation, coagulation, degasification, chlorination, ozonation, neutralization, sorption and ion exchange [3]. But there are several limitations of physicochemical

Correspondence: ayman_ibrahim@nwrc.gov.eg

Microbiology Department, National Water Research Center, Al-Qanater Al-Khairiya 13621, Egypt

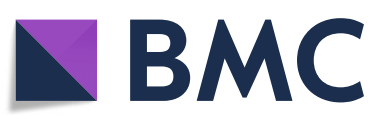

methods such as; high cost, partial treatment, and generating of secondary pollutants, so, the biological methods become an adequate alternative for the removal of pollutants [4].

Food industries always produce wastewaters rich in organic matter, fats, oil \& grease, fatty acids and nitrogenous compounds [5]. The maize processing industry is one of the most common food industries world widely; concerning the production of fructose, glucose, starch, dextrose, food oil, corn flour, gluten, sorbitol, as well as, animal food production and biofuel [6]. Depending on the raw material processed, the sludge may be rich in carbohydrates, lipids or proteins. The production of canned maize produces a high volume of wastewater, with high chemical (COD) and biochemical oxygen demands (BOD). After mechanical wastewater treatment, the COD of the sludge may be more than $100 \mathrm{~kg} \mathrm{~m}^{-3}$,

(C) The Author(s). 2020 Open Access This article is distributed under the terms of the Creative Commons Attribution 4.0 International License (http://creativecommons.org/licenses/by/4.0/), which permits unrestricted use, distribution, and reproduction in any medium, provided you give appropriate credit to the original author(s) and the source, provide a link to the Creative Commons license, and indicate if changes were made. The Creative Commons Public Domain Dedication waiver (http://creativecommons.org/publicdomain/zero/1.0/) applies to the data made available in this article, unless otherwise stated. 
because of the high content of the corn starch [7]. Beszedes et al. [6] evaluated the organic content of corn processing sludge; they found that COD and BOD concentrations were 70 and $58 \mathrm{~kg} \mathrm{~m}^{-3}$.

Microorganisms have been extensively used under aerobic or anaerobic conditions to remediate such industrial wastes; they have an amazing capacity to degrade a variety of organic compounds [8]. Bacillus cereus, Bacillus subtilis, Enterobacter, Streptococcus faecalis, Escherichia coli, and Saccharomyces are microorganisms frequently found in dairy wastewaters and have been found, as indigenous microflora, in bio-treatment $[9,10]$. Pseudomonas was used for the treatment of effluent from leather industry by Selvi and co-workers [11]. Bacillus licheniformis was used to remove $55 \%$ of $100 \mathrm{mg} \mathrm{L}^{-1}$ of phenanthrene [12]. Burkholderia, Pseudomonas and Betaproteobacterium were reported by Ewida [13] as the best biodegrading bacteria for alachlor and endosulfan.

The aerobic biodegradation of food processing liquid wastes with high content of COD was previously suggested by McIntosh and McGeorge [14] and applied by Eckenfelder [15] who have been use aerated lagoons to remove high contents of COD and BOD from liquid wastes of canning of fruits and vegetables. When the waste effluent content of COD and BOD were ranged between 700 and $900 \mathrm{mg} \mathrm{L}^{-1}$ the removal percentage was up to $90 \%$. As their values increased between 3000 to $4000 \mathrm{mg} \mathrm{L}^{-1}$ the removal percentage was $70 \%$. The percentage of removal was decreased to $55 \%$ when the values of COD and BOD reached 7000 to $8000 \mathrm{mg} \mathrm{L}^{-1}$. The author mentioned that the reason for such effect was attributed to the depletion in dissolved oxygen (DO) concentration during the experiment [15]. Where DO concentration was $1.5 \mathrm{mg} \mathrm{L}^{-1}$ before starting aeration, and reached $6 \mathrm{mg} \mathrm{L}^{-1}$ during the test, and finally come down to $0.3 \mathrm{mg} \mathrm{L}^{-1}$ at the end, which created unsuitable conditions for biodegradation.

In the present work, an in-vitro experiment was conducted under ambient conditions, with extensive aeration (to recover the problem of DO depletion) for maize processing wastewater. The following objectives were considered; (i) evaluation of the chemical and microbiological characteristics of maize processing wastewater, (ii) performing a bio-treatment experiment to reduce the high content of organic and nitrogenous compounds found in such wastewater, (iii) isolation, as well as, identification of fungal and bacterial isolates capable of removing the high organic content, to be used as bioremediation tools.

\section{Materials and methods}

\section{Samples collection}

Three maize processing wastewater samples were collected (in triplicates) from an industrial factory for maize products, located in 10th of Ramadan city, Egypt. The main activity of that factory is to produce starch, dextrose, gluten, fructose and corn flour from maize. The collected samples were black in their color, and characterized by their high content of solids.

\section{Quality assessment studies of maize processing wastewater samples}

As soon as samples are received, they quickly subjected to physical, chemical and microbiological investigations. All the analyses were carried out according to the Standard Methods for the Examination of Water and Wastewater [16].

\section{Physico-chemical assessment}

The $\mathrm{pH}$ was measured at $25^{\circ} \mathrm{C}$ using $\mathrm{pH}$ meter (InoLab WTW level 1, electrode with ATC probe WTW Sentix 4), electric conductivity (EC) was measured at $25^{\circ} \mathrm{C}$ using conductivity meter (InoLab Cond level 1), and total suspended solids (TSS) was also measured by keeping a known volume of sample overnight at $105^{\circ} \mathrm{C}$. Phosphate and sulfate were measured using Ion Chromatography, Dionex product, model DX5000. Trace metals; aluminum, barium, cobalt, chromium, copper, iron, manganese, nickel, lead and zinc were measured using the inductively coupled plasma-mass spectrometry, Perkin-Elmer product model SCIEX Elan 9000.

Organic content; Total Kjeldahl Nitrogen (TKN), which is the sum of ammonia-nitrogen plus organically bound nitrogen, was measured using Kjeldahl apparatus (VELP, SCIENTIFICA). BOD; using (OxiTop system WTW) at $20^{\circ} \mathrm{C}$ incubation in a thermostatic incubator chamber for $5 \mathrm{~d}$. COD; using dichromate reflux method, the intensity of the formed complex was measured by the visible Spectrophotometer (HACH 2000).

\section{Microbiological assessment}

Samples were highly turbid, so, serial dilution of samples was carried out until dilution of $10^{5}$. Total count of bacteria (TBC) at 22 and $35^{\circ} \mathrm{C}$, was nominated by spread plate method using plate count agar medium (DIFCO, USA). The total count of coliform bacteria and fecal coliforms was nominated by membrane filter technique using $\mathrm{m}$-endo agar LES and $\mathrm{m}$-FC agar, respectively (MERCK, Germany). Furthermore, the total fungal count (TFC) (including molds and yeasts) was measured by spread plate method using sabauroud agar medium (DIFCO, USA) with direct identification of fungi based on colonial morphology (diameter, color, texture, mode of growth, pigmentation and exudates production).

Salmonella was detected by adding $10 \mathrm{~mL}$ of each wastewater sample to $50 \mathrm{~mL}$ of sterile tetrathionate broth base, and incubated at $37^{\circ} \mathrm{C}$ for $5 \mathrm{~d}$. One milliliter was inoculated on bismuth sulfite agar plate in each day 
and incubated at $37^{\circ} \mathrm{C}$ for further $24 \mathrm{~h}$, the growing of black colonies was considered as presumptive Salmonella.

\section{Bio-treatment of maize processing wastewater using indigenous microorganisms Conducting an in-vitro experiment}

It was designed according to McIntosh and McGeorge [14] who recommended the incubation of food processing wastewaters under aeration to reduce their high COD content. A modification has been performed by creating excessive oxygen during the days of the experiment. So, a mixture of the three maize processing wastewater samples was made using $3 \mathrm{~L}$ of each. The experiment was initiated using a set of triplicate batches of $5 \mathrm{~L}$ Erlenmeyer flasks, enriched with $2 \mathrm{~L}$ of the mixture sample. The three $5 \mathrm{~L}$ batches were incubated under ambient conditions $\left(25^{\circ} \mathrm{C}\right)$ with shaking at $120 \mathrm{rpm}$ for $30 \mathrm{~d}$ (to create excessive aeration; a large volume of air was left in each flask, and all were incubated with shaking). Another $2 \mathrm{~L}$ Erlenmeyer flask enriched with $2 \mathrm{~L}$ of the mixture sample was kept static at room temperature as a control.

\section{Bio-treatment assay}

The biodegradation of the nitrogenous and organic compounds in the mixture of corn processing wastewater was monitored by measuring; TKN, BOD, COD, DO and $\mathrm{pH}$. The biomass growth rate was followed up by measuring TBC and TFC by pour plate method at $30^{\circ} \mathrm{C}$, using plate count agar and sabouraud agar media, respectively. All the tests were measured twice a week through the period of the experiment. At the end of the experiment, nitrite and nitrate concentrations were also evaluated to check for the extent of nitrification.

\section{Microbial identification}

The identification of microorganisms involved in biotreatment was carried out by comparing the community profile of the mixture of corn wastewater samples, at the beginning of the bio-treatment and after it finished. The predominated microbial strains were identified by means of Analytical Profile Index (API) $20 \mathrm{C}$ kit profiling (for yeasts), API $20 \mathrm{E}$ profiling (for Enterobacteriaceae), API $50 \mathrm{CHB}$ (for bacilli) and API staph (for staph bacteria).

\section{Results and discussion}

\section{Quality assessment studies for maize processing wastewater samples}

The results of the physico-chemical analyses of maize processing wastewater samples are described in Table 1. They were characterized by a high content of phosphate and sulfate; where their values were ranged from 3650 to $3900 \mathrm{mg} \mathrm{L}^{-1}$ and 3900 to $4700 \mathrm{mg} \mathrm{L}^{-1}$, respectively. Heavy metals were also detected in high concentrations, especially copper, iron, manganese and zinc where their values were ranged from 217 to 280 , from 226 to 273 , from 390 to 430 and from 228 to $240 \mathrm{mg} \mathrm{L}^{-1}$, respectively.

The maize processing wastewater samples were also very rich in their content of nitrogenous and organic compounds where the TKN was ranged from 2190 to $2330 \mathrm{mg} \mathrm{L}^{-1}$, the BOD was ranged from 8800 to 9000 $\mathrm{mg} \mathrm{L}^{-1}$ and the COD was ranged from 11,200 to 12,100 $\mathrm{mg} \mathrm{L}^{-1}$. Concerning the high values obtained from the physico-chemical analyses of maize processing wastewater samples, there are many authors who have been evaluated the chemical composition of corn processing sludge all over the world [17-20]. Cronje [21] found that phosphate and sulfate constituted about 0.37 and $0.43 \%$ of the dried sludge produced from wastewater treatment of corn processing for the production of glucose, dextrose and corn flour in South Africa. van Lune [22] reported the high metal concentration in soil fertilized by sludge produced from maize by-products in Netherland.

The high content of nitrogenous and organic compounds obtained in the present study was expected, as it is well known that corn kernel is consists mainly from starch and gluten (70\%) [6], so, the wastewaters come up from such highly enriched constituents will be saturated with carbohydrates, proteins, amino acids and nitrogenous substances. In accordance with the present results, Ross [18] reported that the mean value of BOD, COD and TKN of corn processing sludge collected from a factory manufacturing corn flour from maize in South Africa was 7194,9210 and $1900 \mathrm{mg} \mathrm{kg}^{-1}$, respectively.

The microbiological assessment of maize processing wastewater samples indicated their contamination with elevated counts of bacteria, as stated in Table 1. The presence of coliform bacteria in such high counts (more than 10 million CFU $100 \mathrm{~mL}^{-1}$ of total coliforms and more than 1 million CFU $100 \mathrm{~mL}^{-1}$ of fecal coliforms) might be due to the mixing of sewage effluent with industrial wastewater, by the factory. The test for Salmonella as pathogenic bacteria was negative. On the other hand, the community of fungi was yeast only, where the grown colonies on each plate were the same in cultural characteristics (homogenate community).

\section{Bio-treatment of maize processing wastewater using indigenous microorganisms}

The aerobic biodegradation was the tool used in the present study; the batch experiment was conducted by diffusing excessive oxygen through the wastewater contents, taking into account, the high carbon, nitrogen and other elements content of such wastewater, as well as, the elevated counts of bacteria and yeasts. The values of TKN, BOD, COD, DO, pH, TBC and TFC were followed up in triplicates and the mean was recorded. The 
Table 1 Quality assessment of maize processing wastewater samples

\begin{tabular}{|c|c|c|c|c|}
\hline \multirow[t]{2}{*}{ Analysis } & \multirow[t]{2}{*}{ Unit } & \multicolumn{3}{|c|}{ Maize processing wastewater } \\
\hline & & Sample 1 & Sample 2 & Sample 3 \\
\hline \multicolumn{5}{|c|}{ Physico-chemical characteristics } \\
\hline $\mathrm{pH}$ & & 7.3 & 7.4 & 7.2 \\
\hline EC & $\mu \mathrm{S} \mathrm{cm}^{-1}$ & 1475 & 1520 & 1290 \\
\hline TSS & $\mathrm{mg} \mathrm{L}^{-1}$ & 160,000 & 190,000 & 130,000 \\
\hline Phosphate & $\mathrm{mg} \mathrm{L}^{-1}$ & 3700 & 3900 & 3650 \\
\hline Sulfate & $\mathrm{mg} \mathrm{L}^{-1}$ & 4300 & 4700 & 3900 \\
\hline Aluminum & $\mathrm{mg} \mathrm{L}^{-1}$ & 26 & 24 & 19 \\
\hline Barium & $\mathrm{mg} \mathrm{L}^{-1}$ & 19 & 12 & 7 \\
\hline Cobalt & $\mathrm{mg} \mathrm{L}^{-1}$ & 9 & 10 & 6 \\
\hline Chromium & $\mathrm{mg} \mathrm{L}^{-1}$ & 18 & 16 & 9 \\
\hline Copper & $\mathrm{mg} \mathrm{L}^{-1}$ & 217 & 280 & 240 \\
\hline Iron & $\mathrm{mg} \mathrm{L}^{-1}$ & 226 & 273 & 230 \\
\hline Manganese & $\mathrm{mg} \mathrm{L}^{-1}$ & 427 & 430 & 390 \\
\hline Nickel & $\mathrm{mg} \mathrm{L}^{-1}$ & 24 & 19 & 12 \\
\hline Lead & $\mathrm{mg} \mathrm{L}^{-1}$ & 3 & 1.2 & 2.1 \\
\hline Zinc & $\mathrm{mg} \mathrm{L}^{-1}$ & 228 & 240 & 236 \\
\hline \multicolumn{5}{|l|}{ Organic content } \\
\hline TKN & $\mathrm{mg} \mathrm{L}^{-1}$ & 2330 & 2190 & 2210 \\
\hline $\mathrm{BOD}$ & $\mathrm{mg} \mathrm{L}^{-1}$ & 8800 & 9000 & 9220 \\
\hline COD & $\mathrm{mg} \mathrm{L}^{-1}$ & 11,200 & 12,100 & 12,000 \\
\hline \multicolumn{5}{|c|}{ Microbiological assessment $\left(\right.$ Count $\left.\times 10^{4}\right)$} \\
\hline $\operatorname{TBC} 22^{\circ} \mathrm{C}$ & CFU mL ${ }^{-1}$ & 220 & 135 & 190 \\
\hline $\operatorname{TBC} 35^{\circ} \mathrm{C}$ & $\mathrm{CFU} \mathrm{mL}^{-1}$ & 300 & 240 & 290 \\
\hline Total coliforms count & CFU $100 \mathrm{~mL}^{-1}$ & 1660 & 1420 & 1760 \\
\hline Fecal coliforms count & CFU $100 \mathrm{~mL}^{-1}$ & 1250 & 1120 & 1190 \\
\hline Salmonella & Presence/Absence & absent & absent & absent \\
\hline TFC & CFU mL ${ }^{-1}$ & 1000 & 1200 & 700 \\
\hline
\end{tabular}

influence of microorganisms on the wastewater content was obvious comparing the characters of the mixture of wastewater before and after the test is done, as ensured in Fig. 1.

The concentration of TKN in the mixture sample of maize processing wastewater was $2330 \mathrm{mg} \mathrm{L}^{-1}$. The application of bio-treatment under excess oxygen gives the chance to indigenous microorganisms to reduce the concentration to $420 \mathrm{mg} \mathrm{L}^{-1}$ with removing percentage of $82 \%$, as explained by Fig. 2a. The effect of biodegradation was observed from the first day of the experiment, but it starts to distend from the day 6 to day 27. The concentrations of nitrite and nitrate were also measured at the end of the experiment; the first was less than $0.2 \mathrm{mg} \mathrm{L}^{-1}$, while the last was $44 \mathrm{mg} \mathrm{L}^{-1}$, ensuring that there is no extent for nitrification and the by-products of biodegradation of nitrogenous compounds are nontoxic.
Concerning the reduction of carbon content during the bio-treatment, the results were illustrated in Fig. $2 \mathrm{~b}$ and $\mathrm{c}$. The BOD and COD values were come down extensively as the test is going on. BOD values were reduced from 9000 to $220 \mathrm{mg} \mathrm{L}^{-1}$ with removing percentage of $98 \%$, COD content was reduced from 12 , 000 to $430 \mathrm{mg} \mathrm{L}^{-1}$ with removing percentage up to $97 \%$.

It is clear that BOD and COD biodegradation set of from day 3 to 24 of the expirement. These results are in accordance with those recorded by Tricolici et al. [23] who studied the bio-treatment of dairy industry wastewater rich in organic and nitrogenous compounds in Romania. They found that bacteria with help of microalgae could remove 68 and $91 \%$ of TN and COD, respectively. The reduction in COD was also reported by Ross [18] who used indigenous bacteria to treat corn processing wastewater sludge; it was ranged from 91 to $95 \%$. 

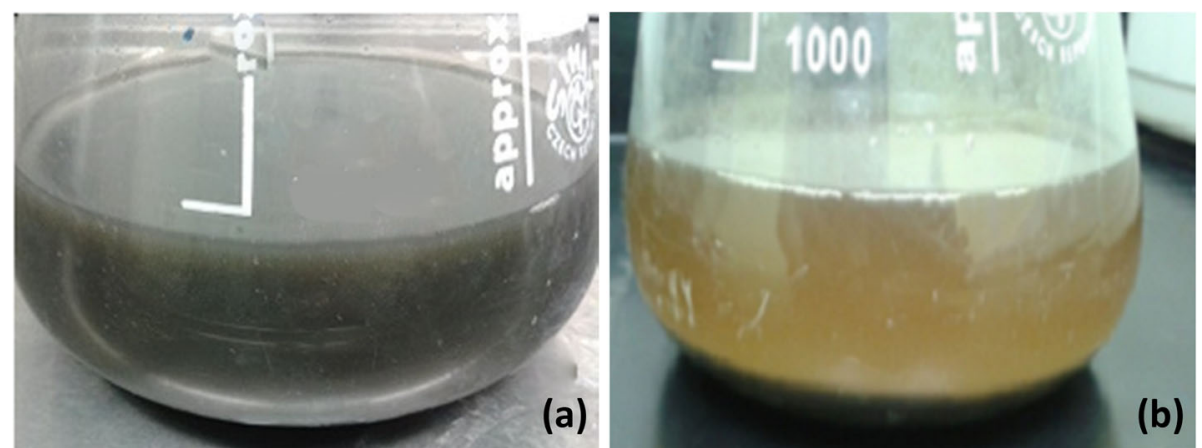

Fig. 1 Influence of indigenous microorganisms on maize processing wastewater (a) wastewater at the beginning of the test (b) at the end
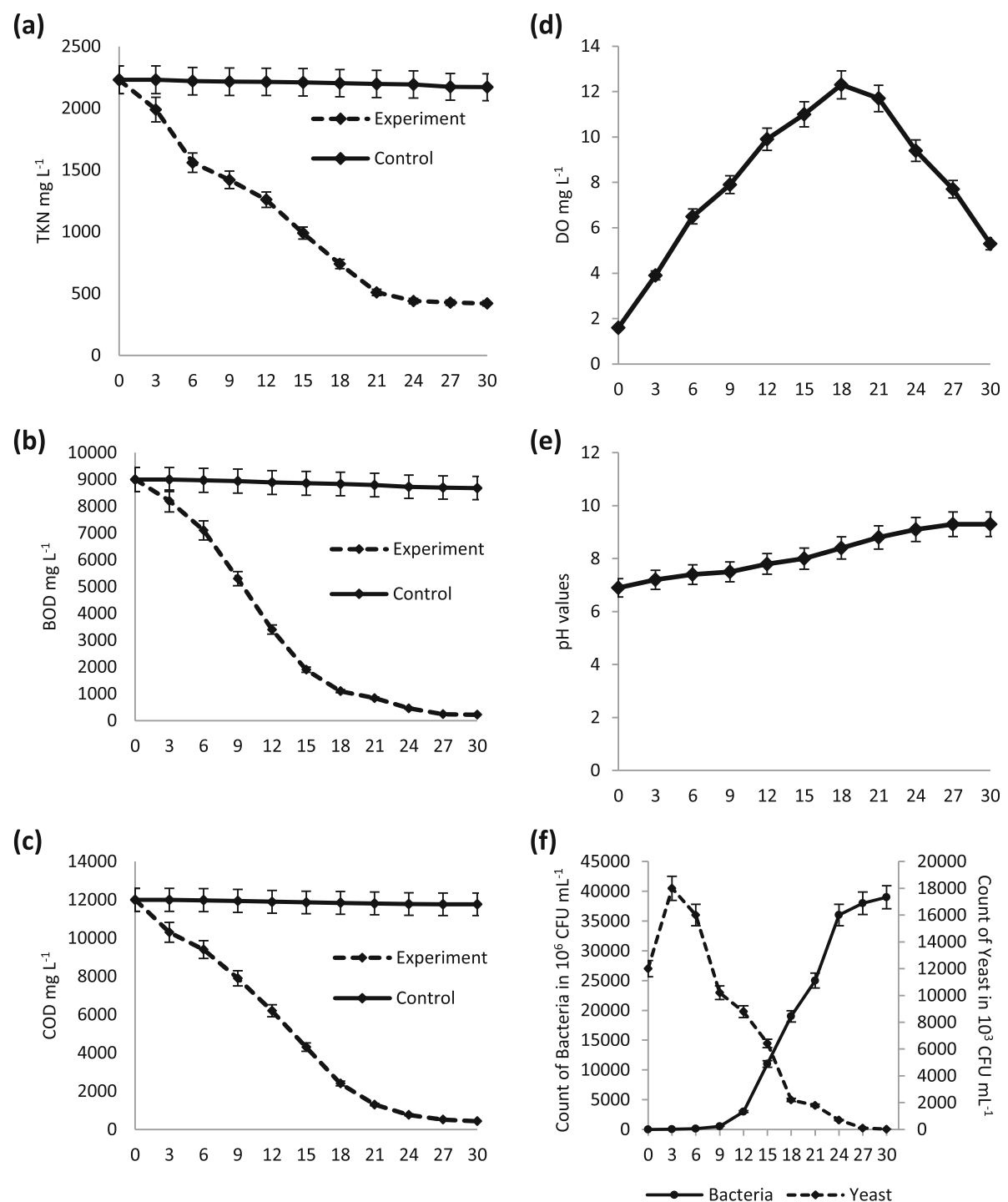

Fig. 2 Illustrations concerning bio-treatment of maize processing wastewater by indigenous bacteria (a) reduction in TKN (b) reduction in COD (c) reduction in $\mathrm{BOD}(\mathbf{d}) \mathrm{DO}$ concentrations during the experiment $(\mathbf{e})$ elevation in $\mathrm{pH}$ values (f) growth rates of bacteria and yeast during the experiment 
Moreover, Abdel-Fatah and co-workers [24] applied the same idea of excessive aeration on corn processing wastewater in Egypt. They recorded that COD and BOD were reduced from 8000 to $700 \mathrm{mg} \mathrm{L}^{-1}$, and from 4500 to $400 \mathrm{mg} \mathrm{L}^{-1}$, respectively.

The initial DO concentration of maize processing wastewater was very low before starting aeration by shaking $\left(1.6 \mathrm{mg} \mathrm{L}^{-1}\right)$ and increased to $7 \mathrm{mg} \mathrm{L}^{-1}$ at day 6 , by the effect of shaking. The metabolic activities of indigenous microorganisms gradually increased by the effect of excess oxygen diffused in wastewater, even so, the expected depletion of DO was recovered during the period of day 6 to 27, due to continuous shaking where DO ranged from 6 to $12 \mathrm{mg} \mathrm{L}^{-1}$ (the period of maximum activity for biodegradation obtained by indigenous microorganisms as ensured by the previous results). Then the DO was reduced to 5.3 at the end of the test (Fig. 2d). Such findings are in accordance with those reported by Abdel-Fatah et al. [24] who mentioned that increasing the oxygen content in the reactor and elevating the biomass concentration lead to high biodegradation capacity. Concerning the elevated DO concentrations during day 12 to 24 (ranged between 9 to $12 \mathrm{mg} \mathrm{L}^{-1}$ ) which beyond the known saturation level $\left(8-9 \mathrm{mg} \mathrm{L}^{-1}\right)$. That might be arise from the fact that equilibration of the oxygen content of water with the air above it is happen in slowflowing streams but in fast-flowing streams, the DO readings were elevated over $100 \%$ air saturation. DO concentration reached $15-18 \mathrm{mg} \mathrm{L}^{-1}$ in natural water falls [25]. So, the saturation level is considered when the surface of water is in static phase, but in case of shaking conditions, the air's oxygen permeates through the water, leading to over saturation conditions. McDaniel and Bailey [26] have been used shaking and agitation to produce high DO concentration in culture media.

The $\mathrm{pH}$ was monitored during the batch experiment period; the results were clarified in Fig. 2e. It was neutral through the first week and starts to be slightly alkaline, ranging from 7.5 to 8 through the second week. As the biodegradation products increased with time, the $\mathrm{pH}$ of the mixture increased, and the solution became moderately alkaline at the end, where the $\mathrm{pH}$ reached 9.3.

The biomass growth rate was carried out by counting of the viable bacterial and yeast cells, the results obtained were illustrated in Fig. 2f. The count of bacteria exploded during bio-treatment, where it was $2 \times 10^{6}$ $\mathrm{CFU} \mathrm{mL} \mathrm{mL}^{-1}$ at the beginning of the test, and become $4 \times$ $10^{10} \mathrm{CFU} \mathrm{mL} \mathrm{mL}^{-1}$ at the end. On the other hand, yeasts were predominated in the fungal community, the mycelial fungi were not present. The count of yeast was $12 \times$ $10^{6} \mathrm{CFU} \mathrm{mL} \mathrm{mL}^{-1}$ at the start time and decreased during bio-treatment to become $2.2 \times 10^{4} \mathrm{CFU} \mathrm{mL}^{-1}$ at the end. The identification of the microbial community before and after bio-treatment indicated that yeast group constituted $26 \%$ and bacterial group $74 \%$, of the microbial community of the tested maize processing wastewater. Yeast was identified by means of API $20 \mathrm{C}$ kits profiling as Saccharomyces cerevisiae, while bacteria, were identified by means of API $20 \mathrm{E}$, API $50 \mathrm{CHB}$ and API staph kits profiling as E. coli, Enterobacter, Citrobacter, Proteus, Bacillus lichiniformis, Bacillus amyloliquefaciens, Bacillus subtilis, Staphylococcus and non-identified Gram-negative bacteria. They were counting for 8, 6, 4, $5,10,12,12,5$ and $12 \%$ of the community, respectively. At the end of bio-treatment the survived microorganisms were $S$. cerevisiae, B. lichiniformis, B. amyloliquefaciens and B. subtilis constituting 1,29, 37 and $33 \%$ of the community, respectively.

Biodegradation of organic compounds of maize processing wastewater by the indigenous microorganisms was noticed from the first day of the in vitro conducted experiment. That could be initiated by yeast $(S$. cerevisiae) which constituted the largest percentage in the microbial community. S. cervisiea has been reported in the literature as a strong bio-degrader especially for wastes rich in protein and carbohydrates [27-29]. As the $\mathrm{pH}$ of the solution tends to be alkaline; the growth of yeast and consequently, their influence on biodegradation was slowed down. It was reported by Yalcin and Ozbas [30] that $S$. cerevisiae show better activity at $\mathrm{pH} 5$ to 7 , and strongly suppressed at $\mathrm{pH} 10$. As the bio-treatment experiment going on, in the third week, bacteria start to explode in numbers and their influence in biodegradation become obvious.

Actually not all the bacterial genera identified at the beginning of the experiment have been shared in biodegradation, because Gram-negative bacteria as E. coli, Enterobacter, Citrobacter and Proteus, as well as, Grampositive cocci as Staphylococcus were found to be sensitive to alkaline $\mathrm{pH}$. On the other hand, B. lichiniformis, $B$. amyloliquefaciens and B. subtilis had shown strong ability to survive alkaline $\mathrm{pH}$, they grown well and continuing the bio-treatment process successfully. Padan et al. [31] found that E. coli when grown in LuriaBertani media at $\mathrm{pH} 7$, all genes encoding for adenosine triphosphate (ATP) cycle were working well, but at $\mathrm{pH}$ 8.5 those genes did not express, so, the ATP cycle corrupted, consequently, bacterial cells destroyed. While the encoding genes for ATP cycle in B. subtilis are still expressed even at $\mathrm{pH} 9.5$ and give the same bacterial density as at $\mathrm{pH} 7$.

\section{Conclusions}

Maize processing wastewater was enriched with a high content of nitrogenous and organic compounds. The indigenous yeast and bacteria, under ambient conditions with diffusion of excessive oxygen could be removed up to $85 \%$ of nitrogenous compounds and up to $95 \%$ of 
organic matters. The microorganisms shared in biodegradation are S. cerevisiae, B. lichiniformis, B. amyloliquefaciens and B. subtilis. The use of such technique for industrial wastewater treatment before discharge to the sewerage system is recommended. Further studies should be carried out on the produced sludge to be used as fertilizer.

\section{Acknowledgements}

Not applicable.

\section{Author's contributions}

The author read and approved the final manuscript.

\section{Funding}

Not applicable.

\section{Availability of data and materials}

All data generated or analyzed during this study are of my own work and it is my pleasure to be available publically.

\section{Competing interests}

The author declares that he has no competing interests.

Received: 29 August 2019 Accepted: 9 January 2020

Published online: 20 January 2020

\section{References}

1. Chhonkar PK, Datta SP, Joshi HC, Pathak H. Impact of industrial effluents on soil health and agriculture- Indian experience: part II - tannery and textile industrial effluents. J Sci Ind Res India. 2000;59:446-54.

2. Orhon D, Gorgun E, Germirli F, Artan N. Biological treatability of dairy wastewaters. Water Res, 1993:27:625-33.

3. Healy MG, Bustos RO, Solomon SE, Devine C, Healy A. Biotreatment of marine crustacean and chicken egg shell waste. In: Moo-Young M, Anderson WA, Chakrabarty AM, editors. Environmental biotechnology. Dordrecht: Springer; 1995. p. 302-19.

4. Porwal HJ, Mane AV, Velhal SG. Biodegradation of dairy effluent by using microbial isolates obtained from activated sludge. Water Resour Ind. 2015;9: $1-15$.

5. Hawley JK. Assessment of health risk from exposure to contaminated soil. Risk Anal. 1985:5:289-302.

6. Beszedes S, Kertesz S, Laszlo Z, Szabo G, Hodur C. Biogas production of ozone and/or microwave-pretreated canned maize production sludge. Ozone-Sci Eng. 2009;31:257-61.

7. Eskicioglu C, Kennedy KJ, Droste RL. Characterization of soluble organic matter of waste activated sludge before and after thermal pretreatment. Water Res. 2006:40:3725-36.

8. Atlas RM, Bartha R. Microbial ecology: fundamentals and applications. 4th ed. Menlo Park: Benjamin Cummings; 1998.

9. Janczukowicz W, Zielinski M, Debowski M. Biode gradability evaluation of dairy effluents originated in selected sections of dairy production. Bioresour Technol. 2008:99:4199-205.

10. Madigan MT, Martinko JM, Parker J. Brock biology of microorganisms. 9th ed. Upper Saddle River: Prentice Hall; 2000.

11. Selvi AT, Anjugam E, Devi RA, Madhan B, Kannappan S, Chandrasekaran B. Isolation and characterization of bacteria from tannery effluent treatment plant and their tolerance to heavy metals and antibiotics. Asian J Exp Biol Sci. 2012:3:34-41.

12. Jahin HS, Gaber SE, Ewida AY. Biodegradation of phenanthrene by native bacterial strains isolated from river Nile water in Egypt. Nat Sci. 2014;12:1-8.

13. Ewida AYI. Biodegradation of alachlor and endosulfan using environmental bacterial strains. World Appl Sci J. 2014;32:540-7.

14. McIntosh GH, McGeorge GG. Year around lagoon operation. Food Process. 1964;25:82-6.

15. Eckenfelder WW Jr. New design advances in biological treatment of industrial wastes. In: 17th Annual Industrial Wastes and Pollution Control Conference. Oklahoma: Aerated lagoon treament of food processing wastes. EPA; 1968
16. APHA. Standard methods for the examination of water and wastewater. 23rd ed. Washington, DC: American Public Health Association; 2017.

17. Beccari M, Mappelli P, Tandoi V. Relationship between bulking and physicochemical-biological properties of activated sludges. Biotechnol Bioeng. 1980;22:969-79.

18. Ross WR. The phenomenon of sludge pelletization in the anaerobic treatment of a maize processing waste. Water SA. 1984;10:197-204.

19. Singh R, Verma RS, Yadav Y. Use of industrial waste water for agricultural purpose: $\mathrm{Pb}$ and $\mathrm{cd}$ in vegetables in Bikanar city, India. Curr World Environ. 2012;7:287-92.

20. Sterrett SB, Chaney RL, Gifford CH, Mielke HW. Influence of fertilizer and sewage sludge compost on yield and heavy metal accumulation by lettuce grown in urban soils. Environ Geochem Hlth. 1996;18:135-42.

21. Cronje CPR. Treatment of glucose-starch waste by the anaerobic filter process [Master's thesis]. Cape Town: Univ of Cape Town; 1973.

22. van Lune P. Cadmium and lead in soils and crops from allotment gardens in the Netherlands. Neth J Agr Sci. 1987;35:207-10.

23. Tricolici O, Bumbac C, Postolache C. Microalgae-bacteria system for biological wastewater treatment. J Environ Prot Ecol. 2014;15:268-76.

24. Abdel-Fatah MA, Sherif HO, Hawash SI. Investigation on wastewater treatment of maize processing effluent. Int J Sci Eng Res. 2015;6:264-8.

25. FE. "Dissolved oxygen." Fundamentals of environmental measurements. Fairborn: Fondriest Environmental, Inc:; 2013.

26. McDaniel LE, Bailey EG. Effect of shaking speed and type of closure on shake flask cultures. Appl Microbiol. 1969;17:286-90.

27. Cabras P, Meloni M, Pirisi FM, Farris GA, Fatichenti F. Yeast and pesticide interaction during aerobic fermentation. Appl Microbiol Biot. 1988;29:298301.

28. Wang $J$, Chen C. Biosorption of heavy metals by Saccharomyces cerevisiae: a review. Biotechnol Adv. 2006;24:427-51.

29. Bahafid W, Joutey NT, Sayel H, Iraqui-Houssaini M, El Ghachtouli N. Chromium adsorption by three yeast strains isolated from sediments in Morocco. Geomicrobiol J. 2013:30:422-9.

30. Yalcin SK, Ozbas ZY. Effects of pH and temperature on growth and glycerol production kinetics of two indigenous wine strains of Saccharomyces cerevisiae from Turkey. Braz J Microbiol. 2008;39:325-32.

31. Padan E, Bibi E, Ito M, Krulwich TA. Alkaline $\mathrm{pH}$ homeostasis in bacteria: new insights. BBA-Biomembranes. 2005;1717:67-88.

\section{Publisher's Note}

Springer Nature remains neutral with regard to jurisdictional claims in published maps and institutional affiliations.

Ready to submit your research? Choose BMC and benefit from:

- fast, convenient online submission

- thorough peer review by experienced researchers in your field

- rapid publication on acceptance

- support for research data, including large and complex data types

- gold Open Access which fosters wider collaboration and increased citations

- maximum visibility for your research: over $100 \mathrm{M}$ website views per year

At BMC, research is always in progress.

Learn more biomedcentral.com/submissions 